\title{
Incorporation of coconut milk residue in pasta: Influence on cooking quality, sensory and physical properties
}

\author{
P.P. Shameena Beegum*, Monika Sharma', M.R. Manikantan*, R. Pandiselvam \\ and R.K. Gupta ${ }^{2}$ \\ ICAR-Central Plantation Crops Research Institute, Kasaragod-671 124, Kerala, India \\ ${ }^{1} I C A R$-National Dairy Research Institute, Southern Regional Station, Adugodi, Bengaluru-560 030, \\ Karnataka, India \\ ${ }^{2}$ ICAR-Central Institute of Post Harvest Engineering and Technology, Ludhiana-141 004, Punjab, India
}

(Manuscript Received: 21-01-2021, Revised:23-04-2021, Accepted:28-05-2021)

\begin{abstract}
A study was conducted to explore the potentiality of coconut milk residue (CMR) for cold extrusion (pasta preparation). Proximate analysis revealed that coconut milk residue is a rich source of crude fibre $(24.03 \%)$ in addition to crude fat $(41.55 \%)$, crude protein $(5 \%)$, total carbohydrates $(26.24 \%)$ and ash content $(0.97 \%)$ at 2.23 per cent moisture. The effect of coconut milk residue upon replacing durum wheat semolina on cooking qualities, colour parameters, textural property and overall sensory acceptability of pasta samples were evaluated. Incorporation of coconut milk residue significantly influenced the observed parameters $(\mathrm{P}<0.01)$. Cooking time was unaffected by incorporating milk residue up to 10 per cent $(\mathrm{P}<0.05)$. Though the addition of residue increased the gruel loss $(0.84$ to $1.34 \%)$, the per cent loss was below the technologically acceptable limit $(<8 \%)$. A similar effect was visualized in water absorption. Conversely, the firmness gets reduced with an increased concentration of coconut milk residue beyond 10 per cent. Pasta with 5 per cent and 10 per cent coconut milk residue were accepted as that of control by the sensory panel. Free fatty acid content was not affected by the period of storage $(\mathrm{P}>0.05)$. Thus, the study recommends incorporating 10 per cent coconut milk residue in durum wheat semolina for pasta preparation. Moreover, the entrepreneurs engaged in the coconut milk/milk powder and virgin coconut oil industry would be benefitted by adopting this venture, wherein they would be able to fetch huge additional income by placing their residue product on an upgraded fast-moving consumer good (FMCG) value chain.
\end{abstract}

\section{Introduction}

Coconut milk residue (CMR) is one of the byproducts obtained during the extraction of coconut milk during the production of packaged milk or coconut milk powder, flavoured coconut milk or virgin coconut oil (VCO). The processing of 500 coconuts generates approximately $25 \mathrm{~kg}$ of coconut milk residue (Beegum et al., 2016). Per cent recovery of coconut milk residue, based on pulverized gratings, generally ranges from 38.5 to 55.6 (Manikantan et al., 2016). Dried and powdered coconut milk residue with a moisture content of 2.86 per cent consists of 5.29 per cent crude protein, 49.24 per cent crude fat, 25.51 per cent crude fibre with 46.50 per cent dietary fibre and 0.93 per cent ash content (Manikantan et al., 2015). The fibre content present in coconut milk residue is higher than cereals, including rice bran, oats, and barley bran; in fact, it is double than wheat bran (Lalitha, 2014). Further, Sindurani and Rajamohan (1998) stated that neutral detergent fibre extracted from coconut kernel effectively reduced serum total cholesterol, LDL cholesterol and triglycerides concentrations in rats. Characterization of CMR revealed that the soluble, insoluble and total dietary fibre content in CMR is 2.7 per cent, 28.4 per cent and 31.1 per cent, respectively, which was more than those present in fruits such as orange, peach and pear (Ng et al., 2010; Gunathilake et al., 2009).

*Corresponding Authors:shameena.pht@gmail.com, manicpcri@gmail.com 
CMR is effective against diabetes, colon cancer, and coronary heart diseases (Trinidad et al., 2003). Despite being an excellent source of nutrients, its use is limited to only a few baking industries and is mainly utilized for animal feed or haphazardly thrown as waste (Trinidad et al., 2003; Manikantan et al., 2016). CMR was explored for protein and dietary fibre enrichment in wheat bread with up to 20 per cent substitution of wheat flour (Gunathilake et al., 2009). Manikantan et al. (2015) attempted the feasibility of CMR in hot extrusion and found that it could be very well utilized in extrusion. However, limited studies have been undertaken to explore the feasibility of CMR for cold extrusion processing.

Pasta is a convenient food prepared through the cold extrusion method. It is the most common processed cereal product next to bread, which people of all ages relish. Pasta products are healthy, delicious and convenient, especially for working women. It is one of the fastest-growing categories in the packaged food market in our country, particularly in urban clusters. Wheat is usually used for pasta preparation because of its gluten content. The addition of water causes the plasticization of proteins, thereby shaping the wheat flour or semolina during extrusion. Due to the properties of gluten and the natural yellow pigment, durum wheat semolina is preferred for pasta making (Padmaja et al., 2015). With the backdrop of several health benefits associated with coconut milk residue, especially as a source of good fibres and further its limited utilization in food products, the present study has been planned to explore the potential of fibre and other components present in the CMR to make pasta. Utilizing CMR in pasta making would serve as a practical solution for residue management and provide an additional source of income for the stakeholders involved in coconut processing.

\section{Materials and methods}

\section{Raw materials}

Semolina was purchased ('Rajdhani' brand) from the local market. CMR obtained after extracting coconut milk was dried at $60-65^{\circ} \mathrm{C}$ in a tray dryer up to 2.5 per cent moisture level and sieved (60 BSS $0.251 \mathrm{~mm}$ ) by a standard sieve shaker.

\section{Pasta preparation}

Preliminary standardization revealed that replacement of semolina with more than 20 per cent affects the shape and texture of pasta during cooking. Hence, semolina was supplemented with CMR up to 20 per cent $(0,5,10,15$ and $20 \%)$. The mixing chamber of the cold extruder was filled with the prepared flour (Model: Dolly, La Monferina, Asti, Italy). Further, water was added and mixed uniformly for $10 \mathrm{~min}$. A metal extruder attachment was placed in the machine fitted with a spiral-shaped die. The length of each pasta was fixed to $5 \mathrm{~cm}$. Samples were then dried at $50 \pm 5^{\circ} \mathrm{C}$ for $5 \mathrm{~h}$ in a hot air oven till they attained 6-7 per cent moisture. It was packed in $100 \mu$ thick polyethylene bags without any preservative under ambient conditions $\left(32 \pm 3^{\circ} \mathrm{C}\right)$ till further use.

\section{Cooking time and cooking quality evaluation}

Pasta samples were cooked as per the method followed by Yadav et al. (2014). Pasta sample (25 g) was added to $250 \mathrm{~mL}$ boiling water (in a $500 \mathrm{~mL}$ glass beaker) and cooked until the disappearance of the hard central core. Time taken for cooking was noted.

Solids lost in cooking water (gruel loss) and water absorption was found using the following formula (AACC method 66-50). Cooking loss was determined in water collected from each sample after cooking by evaporation to constant weight in a hot air oven at $105^{\circ} \mathrm{C}$.

$$
\begin{aligned}
& \text { Gruel loss }(\%)=\quad \frac{\text { Weight of dry residue }}{\text { Initial weight of raw pasta }} \times 100 \text { (1) } \\
& \text { Water absorption }(\%)=\frac{\text { Weight of cooked pasta-weight of raw pasta }}{\text { Weight of raw pasta }} \times 100(2)
\end{aligned}
$$

\section{Colour}

The colour of the pasta samples (raw and cooked) was measured using a Hunter Lab colorimeter (Mini Scan XE Plus). Since the pasta samples were light yellow, $L$ (lightness) and $\mathrm{b}$ (yellow-blue) values were observed. $L$ represents black to white $(0-100),+b$ is yellow and $-b$ is blue. The measurements were performed in two replications and repeated 3 times per replicate. 


\section{Textural analysis}

The texture of the cooked pasta samples was measured using a Texture Analyzer (TA-HDi, Stable Micro Systems Ltd., Surrey, UK). The settings were followed, as stated by Yadav et al. (2014). Maximum force in the force-time graph was taken as firmness. Six measurements were taken for each sample.

\section{Sensory acceptability}

A panel of 10 semi-trained judges evaluated the sensory acceptability of cooked pasta samples. $100 \mathrm{~g}$ sample was cooked in $500 \mathrm{~mL}$ water added with $3 \mathrm{~g}$ table salt. After completion of cooking, excess water was drained and $25 \mathrm{~g}$ of cooked pasta from each treatment were served to the panel for comparing evaluating the sensory attributes such as appearance, flavour, taste, texture, mouthfeel, and overall acceptability (OA) using a nine-point hedonic scale. The overall acceptability was considered for the statistical analysis.

\section{Storage studies}

The optimized pasta sample containing CMR packaged in low-density polyethylene (LDPE) pouches and stored at ambient temperature $\left(33 \pm 3^{\circ} \mathrm{C}\right)$ was analysed for changes in free fatty acid content during the three months storage at 30 days interval. To estimate FFA, crude fat was extracted using soxhlet apparatus at every 30 days interval. Fat $(1 \mathrm{~g})$ was mixed with $10 \mathrm{~mL}$ neutral solvent mixture (Diethyl ether and ethanol as 1:1) and titrated against $0.01 \mathrm{~N} \mathrm{KOH}$ with phenolphthalein as indicator. The persistence of pink colour for 15 seconds was taken as the endpoint.

\section{Statistical analysis}

The data obtained were analyzed with the analysis of variance (ANOVA) using a completely randomized design (CRD), and the significance among the mean values was tested using the least significant difference (LSD) method

\section{Results and discussion}

The proximate composition of the raw materials is given in Table 1, which is in accordance with the earlier reports on the composition of semolina and coconut milk residue, respectively (Kaur et al., 2012; Manikantan et al., 2015). Crude fibre obtained

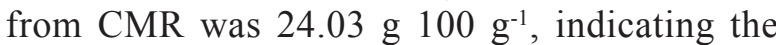
feasibility to enrich the fibre content in pasta. The crude fibre content in rice bran and barley bran are reported to be 11.5 per cent and 14.9 per cent, respectively (Kaur et al., 2012). The fibre content in whole oats is 12.45 per cent (Usman et al., 2010). Thus, it is evident that coconut milk residue is a rich source of crude fibre compared to all these cereals. Similarly, the protein content obtained from CMR (5\%) was comparable with that of maize $(5.5 \%)$, as reported by Hager et al. (2012). CMR is also rich in crude fat $(41.55 \%)$, especially with medium-chain fatty acids that give immense health benefits. The addition of fat improves the pasta texture and makes dough that easily extrudes from the machine apart from enhancing flavour (Fuad and Prabhasankar, 2010). Trinidad et al. (2006) mentioned the relevance of CMR substituted foods with respect to their healthy fatty acids, low glycemic index and weight management. In addition, a good amount of minerals (in terms of ash content) is present in CMR $(0.97 \%)$, which is higher than that of semolina. It contains only 26.24 per cent carbohydrates indicating its role as a low carbohydrate product than wheat, rice and other cereals.

\section{Preparation of pasta}

Preliminary experiments revealed that replacement of semolina with more than 20 per cent CMR resulted in complete disruption of the shape during cooking. Hence the level of incorporation

Table 1. Proximate analysis of the ingredients - Average composition (g $\left.100 \mathrm{~g}^{-1}\right) \pm \mathrm{SD}$

\begin{tabular}{lcccccc}
\hline & Moisture & Crude protein & Crude fat & Total carbohydrates & Crude fibre & Ash \\
\hline CMR & $2.23 \pm 0.31$ & $5.00 \pm 0.02$ & $41.55 \pm 0.13$ & $26.24 \pm 0.67$ & $24.03 \pm 2.2$ & $0.97 \pm 0.02$ \\
Wheat semolina & $13.5 \pm 0.14$ & $11.67 \pm 0.15$ & $1.79 \pm 0.03$ & $71.07 \pm 0.24$ & $1.42 \pm 0.03$ & $0.5 \pm 0.02$ \\
\hline
\end{tabular}

Values represented as mean of three replications with standard deviation 
of CMR in pasta was fixed at $0,10,15$, and 20 per cent.

\section{Cooking quality}

Pasta quality is primarily decided by the cooking performance, which is the ultimate test of acceptability of pasta. During cooking, volume increases and dry matter loss occurs while maintaining the shape without any disintegration (Cleary and Brennan, 2006). The structural changes include starch gelatinization and protein coagulation.

The average time taken for cooking in CMRsupplemented samples varied from 6.5 to $8.0 \mathrm{~min}$ (Table 2), which was lesser than the cooking time of traditional durum wheat pasta, i.e. 7.0 to $9.0 \mathrm{~min}$ (Petitot et al., 2010). Jalgaonkar et al. (2019) reported a cooking time of $5.15 \mathrm{~min}$ as one of the desirable traits of pasta. Substitution up to 10 per cent CMR did not show any significant effect on cooking time $(\mathrm{P}<0.05)$. As the concentration increased further, it took more time to cook, which might be due to the fibres present in CMR, and it took more time for the disappearance of the centre core of pasta. Semolina pasta supplemented with mushroom powder (0-12\%) and defatted soy flour $(0-15 \%)$ also lead to an increase in cooking time (Kaur et al., 2013). In addition, enrichment of pasta with protein through CMR might also result in increased cooking time.

\section{Gruel loss}

Gruel loss is the total solids leached out in gruel during the cooking of pasta, or it is the resistance of pasta against disintegration. The lesser the amount of solids in the cooking water, better is the quality of pasta (Pagani et al., 2007). The gruel loss in the pasta samples was varied from 0.84 to 1.34 per cent $(\mathrm{P}<0.05)$ (Table 2). The lowest gruel loss was observed for the control pasta, whereas the highest

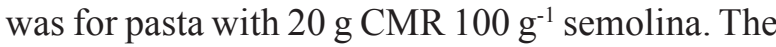
addition of CMR with comparatively larger particle size may increase the cooking loss by loosening the compact structure of pasta (Padmaja et al., 2015). Nevertheless, per cent gruel loss was lesser than previous reports (Eman et al., 2012, Yadav et al., 2014). Pasta samples containing 5 per cent and 10 per cent CMR showed no significant difference in the gruel loss during cooking $(\mathrm{P}>0.05)$. The addition of non-gluten additives causes more disruption to the structure resulting in higher cooking losses (Piwinska et al., 2015). Also, the weaker starchprotein interaction might get disrupted during cooking. Gunathilake and Abeyrathane (2008) observed an increasing tendency for breakage of noodles at a higher level (more than $20 \%$ ) of coconut flour addition due to lowering the gluten content. Nonetheless, the cooking loss in all the samples was below the technologically acceptable limit as per BIS standard ( $\leq 8 \%)$ (Jalgaonkar et al., 2019). As a thumb rule, the residue shall not surpass 7-8 per cent of the dry weight of pasta (Gull et al., 2015). The addition of stabilizers such as carboxymethyl cellulose could be suggested for more than 10 per cent CMR levels so that the residual loss during cooking can be avoided.

\section{Water absorption}

It is the absorption of water gram ${ }^{-1}$ of dry pasta and a test for the nature and type of ingredients and its capability to absorb and hold water. Significant variation was observed $(\mathrm{P}<0.05)$ among the samples (Table 2). As the level of incorporation of CMR

Table 2. Effect of CMR on cooking quality and textural parameter of pasta

\begin{tabular}{|c|c|c|c|c|}
\hline $\begin{array}{l}\text { Level of CMR } \\
\left(\mathrm{g} 100 \mathrm{~g}^{-1}\right)\end{array}$ & $\begin{array}{c}\text { Cooking time } \\
(\mathrm{min}) * *\end{array}$ & $\begin{array}{c}\text { Gruel loss } \\
(\%) * * \\
\end{array}$ & $\begin{array}{c}\text { Water absorption } \\
(\%) * *\end{array}$ & $\begin{array}{c}\text { Firmness } \\
(\mathbf{N}) * *\end{array}$ \\
\hline 0 & $6.53 \pm 0.03^{c}$ & $0.84 \pm 0.15^{\mathrm{c}}$ & $114.52 \pm 0.31^{\mathrm{e}}$ & $24.43 \pm 0.37^{\mathrm{a}}$ \\
\hline 5 & $6.58 \pm 0.01^{\mathrm{c}}$ & $0.95 \pm 0.07^{\mathrm{bc}}$ & $131.66 \pm 2.09^{d}$ & $21.78 \pm 0.74^{b}$ \\
\hline 10 & $6.71 \pm 0.25^{\mathrm{c}}$ & $0.96 \pm 0.05^{\mathrm{bc}}$ & $145.72 \pm 1.37^{\mathrm{c}}$ & $21.90 \pm 0.06^{b}$ \\
\hline 15 & $7.03 \pm 0.06^{\mathbf{b}}$ & $1.10 \pm 0.14^{\mathrm{b}}$ & $150.03 \pm 0.22^{\mathrm{b}}$ & $18.78 \pm 0.22^{\mathrm{c}}$ \\
\hline 20 & $8.03 \pm 0.06^{\mathrm{a}}$ & $1.34 \pm 0.15^{\mathrm{a}}$ & $182.44 \pm 0.58^{\mathrm{a}}$ & $16.54 \pm 0.38^{d}$ \\
\hline
\end{tabular}

**Significant at $1 \%$, Mean value with different letters differ significantly Values are mean replications \pm standard deviation 
increased, the water absorption was also increased (114.52 to $182.44 \%$ for 0 to $20 \%$ CMR incorporation). This increase in water absorption was due to the weaker gluten network. Besides, the high fibre content present in CMR allowed easier water penetration, which resulted in a substantial increase in water absorption. The strong binding ability of fibre can disrupt the gluten matrix (Chillo et al., 2008; Chen et al., 1988). Coconut fibre has the highest water holding, swelling and water retention capacity (Raghavarao et al., 2008).

\section{Colour}

It is an imperative parameter influencing the visual quality of pasta. $L$ and $b$ values are considered important colour attributes in pasta made from semolina (Rayas-Duarte et al., 1996). Colour parameters $L$ (white to black), $b$ (yellow to blue) of raw and cooked pasta are revealed in Table 3. $L$ value of raw pasta ranged from 66.76 to 75.19 , while after cooking, there was an increase from 77.60 to 80.57 . Control pasta showed the maximum value for lightness followed by 20 per cent CMR, 15 per cent $C M R, 10$ per cent $C M R$ and 5 per cent CMR incorporated sample, respectively $(\mathrm{P}<0.001)$. An increase in $L$ value indicates loss of colour during cooking. Nonetheless, samples with 10 per cent and 15 per cent CMR did not show any significant difference $(\mathrm{P}>0.05)$. Similarly, the highest value for $b$ was obtained for the control pasta. Though the samples behaved similarly after cooking to that of raw samples, significant differences were observed among each other $(\mathrm{P}<0.05)$. It was evident that to get a significant change in the yellowness of cooked semolina pasta, at least 10 per cent CMR incorporation was needed. Pasta with 15 per cent and 20 per cent CMR showed a similar $b$ value.

Table 3. Colour attributes of CMR incorporated pasta

\begin{tabular}{lccccc}
\hline Treatments & \multicolumn{2}{c}{$\boldsymbol{L}$ value } & & \multicolumn{2}{c}{$\boldsymbol{b}$ value } \\
\cline { 2 - 3 } \cline { 5 - 6 } & Raw ** & Cooked * & & Raw **Cooked ** \\
\hline 0 & $75.19^{\mathrm{a}}$ & $80.57^{\mathrm{a}}$ & & $17.82^{\mathrm{a}}$ & $12.74^{\mathrm{a}}$ \\
5 & $66.76^{\mathrm{d}}$ & $77.60^{\mathrm{c}}$ & & $13.75^{\mathrm{b}}$ & $12.58^{\mathrm{ab}}$ \\
10 & $70.15^{\mathrm{c}}$ & $78.47^{\mathrm{bc}}$ & & $13.13^{\mathrm{b}}$ & $12.50^{\mathrm{b}}$ \\
15 & $72.26^{\mathrm{b}}$ & $77.86^{\mathrm{bc}}$ & & $13.30^{\mathrm{b}}$ & $12.13^{\mathrm{c}}$ \\
20 & $72.33^{\mathrm{b}}$ & $79.67^{\mathrm{ab}}$ & & $13.58^{\mathrm{b}}$ & $12.12^{\mathrm{c}}$ \\
\hline
\end{tabular}

$* *$ and $*$ Significant at $1 \%$ and $5 \%$ respectively.

Mean value with different letters differ significantly

Values are mean replications \pm standard deviation

\section{Texture}

The texture is one of the most significant quality attributes of cooked pasta. A significant effect was shown by different pasta samples on the firmness after cooking. Table 2 shows that firmness value reduced significantly $(\mathrm{P}<0.05)$ from $24.43 \mathrm{~N}$ to 16.54 N, which is in accordance with Marti and Pagani (2013) in gluten-free pasta. Increasing nongluten proteins weaken the gluten strength and overall structure of the pasta (Rayas-Duarte et al., 1996). Due to the weakening in gluten strength, there was a loss in firmness in cooked pasta (Kaur et al., 2012). However, the semolina pasta replaced with 5 per cent and 10 per cent CMR could retain a similar firmness as that of the control $(\mathrm{P}>0.05)$. This clearly indicated that more than 10 per cent replacement of semolina with CMR would affect the quality of cooked pasta.

\section{Overall acceptability}

The sensory parameters such as appearance, colour, texture, flavour and taste of cooked pasta are essential for acceptability. The overall acceptability (including all sensory parameters) was maximum for control pasta with a mean value of 8.46 (liked very much) and the minimum for pasta containing 20 per cent CMR with 3.7 (Dislike moderately) (Fig.1). The non-significant effect between pasta with 5 per cent and 10 per cent CMR indicates its applicability up to 10 per cent replacement level in pasta. Gunathilake et al. (2009) also mentioned the declining effect of sensory parameters on increasing coconut flour concentration in bread. Bread and noodles with 20 per cent substitution with CMR showed maximum sensory acceptability (Gunathilake and Abeyrathne, 2008).

\section{Free fatty acid content during storage}

FFA content in the control and pasta with 10 per cent CMR incorporation ranged from 0.55 to 0.65 per cent and 0.56 to 0.84 per cent, respectively. Fig. 2 represents the trend in FFA over 90 days of storage period. Though there was a gradual increase in FFA during storage, the level was not enough to give noticeable changes in the product, which was in accordance with the earlier reports (Yadav et al., 2014; Manthey et al., 2008; Kaur et al., 2012). 


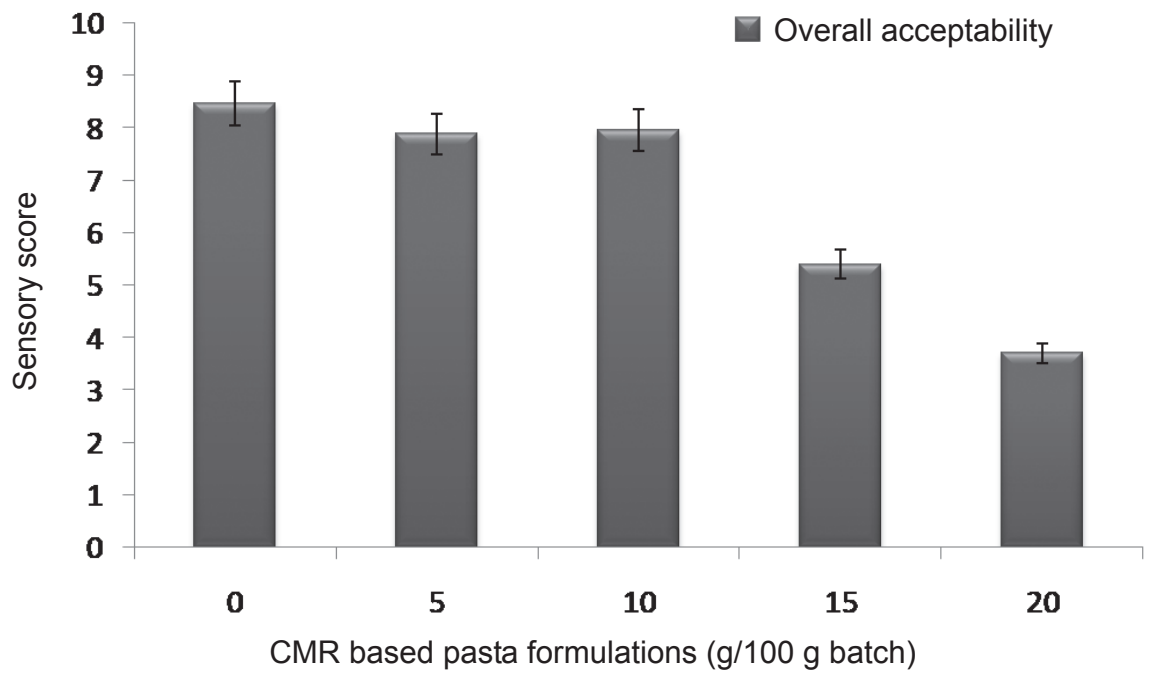

Fig.1. Sensory scores of cooked pasta

\section{Conclusion}

The study exploited the potential of coconut milk residue for the preparation of pasta. The developed pasta had good structural integrity, as evident from the low gruel loss. However, firmness value of the cooked pasta was lower for the fortified sample as compared to control. Results also revealed that coconut milk residue could be incorporated into durum wheat semolina at 10 per cent level as a source of fibre due to its high fibre content (24\%). Recovery of CMR during the extraction of coconut milk ranged from 38.5 to 55.6 per cent. If a coconut processing firm processes coconut milk with 500 nuts per day capacity, then approximately $25 \mathrm{~kg}$ milk residue is generated. The selling price of CMR is ₹ $10-15 \mathrm{~kg}^{-1}$. If it is incorporated for pasta making along with durum wheat semolina, a firm can sell the product at a better price of ₹ $300-700 \mathrm{~kg}^{-1}$. The fortified pasta can provide more than 50 per cent of recommended dietary allowance of fibre in addition to enrichment of pasta with protein. Thus, fortifying semolina pasta with CMR is encouraging due to its nutritional, textural and sensory quality attributes.

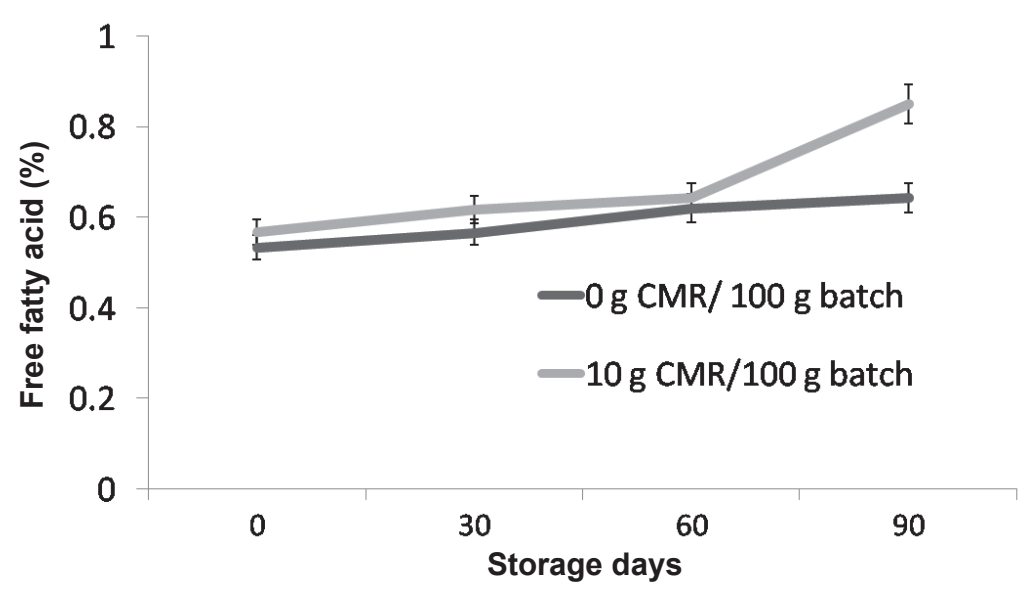

Fig. 2. Effect of incorporation of CMR on the free fatty acid content of pasta during storage 


\section{Acknowledgement}

The authors are grateful to the Project Coordinator, AICRP on Post-harvest Engineering and Technology, ICAR-CIPHET, and the Director, ICAR-CPCRI, for the support. The corresponding author is thankful to Dr. S. Jayasekhar for providing valuable suggestions.

\section{References}

AACC. 2000. Approved Methods of the AACC. $10^{\text {th }}$ Edn American Association of Cereal Chemists.

Beegum, S., Sharma, M., Manikantan, M.R. and Gupta R.K. 2016. Effect of virgin coconut oil cake on physical, textural, microbial and sensory attributes of muffins. International Journal of Food Science and Technology 52(2): 540-549. doi:10.1111/ijfs. 13310.

Chen, H., Rubenthaler, L., Leung, H.K., Baranowski, J.D. 1988. Chemical, physical and baking properties of apple fiber compared with wheat and oat bran. Cereal Chemistry 65(3): 244-247.

Chillo, S., Laverse, J., Falcone, P.M. and Del Nobile, M.A. 2008. Quality of spaghetti in base amaranthus wholemeal flour added with quinoa, broad bean and chick pea. Journal of Food Engineering 84: 101-107.

Cleary, L. and Brennan, C. 2006. The influence of a (1/3)(1/ 4)-b-D-glucan rich fraction from barley on the physicochemical properties and in vitro reducing sugars release of durum wheat pasta. International Journal of Food Science \& Technology 41: 910-918.

Eman, A.M.M., Nassef, S. and basuny, A.M. 2012. Production of high protein quality noodles using wheat flour fortified with different protein products from lupine. Annals of Agricultural Sciences 57(2): 105-112.

Fuad, and Prabhasankar 2010. Role of ingredients in pasta product quality: A review on recent development. Critical Reviews in Food Science and Nutrition 50: 787-798

Gull, A., Kamlesh Prasad, K. and Kumar, P. 2015. Optimization and functionality of millet supplemented pasta. Food Science and Technology 35(4): 626-632

Gunathilake, K.D.P.P. and Abeyrathne, Y.M.R.K. 2008. Incorporation of coconut flour into wheat flour noodles and evaluation of its rheological, nutritional and sensory characteristics. Journal of Food Processing and Preservation 32: 133-142.

Gunathilake, K.D.P.P., Yalegana, C. and Kumara, A.A.N. 2009 Use of coconut flour as a source of protein and dietary fiber in wheat bread. Asian Journal of Food and AgroIndustry 2(3): 382-391.

Hager, A.S., Wolter, A., Jacob, F., Zannini, E. and Arendt, E.K. 2012. Investigation of product quality, sensory profile and ultrastructre of breads made from a range of commercial gluten free flour compared to their wheat counterparts. European Food Research Technology 235: 333-344.

Jalgaonkar, K., Jha, S.K., Mahawar, M.K., Yadav, D.N. 2019. Pearl millet based pasta: optimization of extrusion process through response surface methodology. Journal of Food Science and Technology 56(3): 1134-1144.

Kaur, G., Sharma, S., Nagi, H.P.S. and Dar, B.N. 2012. Functional properties of pasta enriched with variable cereal brans. Journal of Food Science and Technology 49(4): 467-474.

Kaur, G., Sharma S, Nagi, H.P.S. Ranote, P.S. 2013. Enrichment of pasta with different plant proteins. Journal of Food Science and Technology 50(5): 1000-1005.

Lalitha, R. 2014. Coconut flour - a low carbohydrate, gluten free flour- A Review. International Journal of Ayurvedic and Herbal Medicine 4: 1426-1436.

Manikantan, M.R., Arivalagan, M., Mathew, A.C. and Hebbar, K.B. 2015. Effect of processing parameters on recovery of hot process virgin coconut oil and co-products utilization. Journal of Plantation Crops 43: 1-6.

Manikantan, M.R., Mathew, A.C., Madhavan, K., Arumuganathan, T., Arivalagan M., Shameena Beegum and Hebbar, K.B. 2016. Virgin coconut oil hot and fermentation process. Technical bulletin No. 108, Centenary series- 43. ICAR CPCRI, Kasargod, Kerala, India.

Manthey, F.A., Sinha, S., Wolf Hall, C.E. and Hall, C.A. 2008. Effect of flaxseed flour and packaging on shelf life of refrigerated pasta. Journal of Food Processing and Preservation 32: 75-87.

Marti, A. and Pagani, M.A. 2013. What can play the role of gluten in gluten free pasta. Trends in Food Science \& Technology. 31: 63-71.

Ng, S.P., Tan, C.P., Lai, O.M., Long, K. and Mirhosseini, H. 2010. Extraction and characterization of dietary fiber from coconut residue. Journal of Food, Agriculture \& Environment 8(2): 172-177.

Padmaja, G., Menon, R., Krishnan, J.G. and Sajeev, M.S. 2015. Pasta and Noodles from tuber crops as novel health foods. ICAR-Central Tuber Crops Research Institute, Thiruvananthaapuram, p. 204.

Pagani, M.A., Lucisano, M. and Mariotti, M. 2007. Traditional Italian products from wheat and other starchy flours. In: Handbook of Food Products Manufacturing. (Ed.) Hui, Y.H. Wiley, New York

Petitot, M., Boyer, L., Minier, C. and Micard, V. 2010. Fortification of pasta with split pea and faba bean flours: Pasta processing and quality evaluation. Food Research International 43(2): 634-641. 
Piwinska, P. M., Wyrwisz, J., Kurek, M. and Wierzbicka, A 2015. Hydration and physical properties of vacuum-dried durum wheat semolina pasta with high-fiber oat powder. LWT - Food Science and Technology 63: 647-653.

Raghavarao, K.S.M.S., Raghavendra, S.N. and Rastogi, N.K. 2008. Potential of coconut dietary fiber. Indian Coconut Journal 1-7.

Rayas-Duarte, P., Mock, C.M. and Satterleei, L.D. 1996. Quality of spaghetti containing buckwheat, amaranth, and lupin flours. Cereal Chemistry 73(3): 381-387.

Sindurani, J.A. and Rajamohan, T. 1998. Effect of dietary fibre from coconut kernel on cholesterol metabolism. Journal of Clinical Biochemistry and Nutrition 24: 125-132.

Trinidad, T.P., Mallillin, A.C., Divinagraci, Valdez, D.H., Loyola, A.S. and Askali-Mercado, F.C., Castillo, J.C., Encabo, R.R., Masa, D.B., Maglaya, A.C. and Chua,
M.T. 2006. Dietary fibre from coconut flour: a functional food. Innovative Food Science and Emerging Technologies 7: 309-317.

Trinidad, T.P., Valdez, D.H., Loyola, A.S., Mallillin, A.C., Askali, F.C., Castillo, J.C. and Masa, D.B. 2003. Glycaemic index of different coconut (Cocos nucifera)flour products in normal and diabetic subjects. British Journal of Nutrition 90: 551-556.

Usman, S., Nazir, S., Ali, S., Nasreen, Z. and Najim, A. 2010. Determination of biochemical composition of Avena sativa (oat) and to estimate the effect of high fiber diet on hypocholestrolemic rat. Bangladesh Research Publications Journal 4: 312-319.

Yadav, D.N., Sharma, M., Chikara, N., Anand, T. and Bansal, S. 2014. Quality characteristics of vegetable-blended wheat-pearl millet composite pasta. Agricultural Research 3: 263-270. 